\title{
The Raclawka Valley - an example of an educational geosite related to the development of a Paleozoic carbonate platform
}

\author{
Dolina Racławki - przykład geostanowiska edukacyjnego
}

związanego z rozwojem paleozoicznej platformy węglanowej

\author{
Stanisław Szczurek, Marta Bąk, Pawel Dulemba \\ AGH University of Science and Technology, Faculty of Geology, Geophysics and Environmental Protection, \\ al. Mickiewicza 30, 30-059 Kraków; \\ e-mails: szczurek@geol.agh.edu.pl,martabak@agh.edu.pl,pawel.dulemba@gmail.com
}
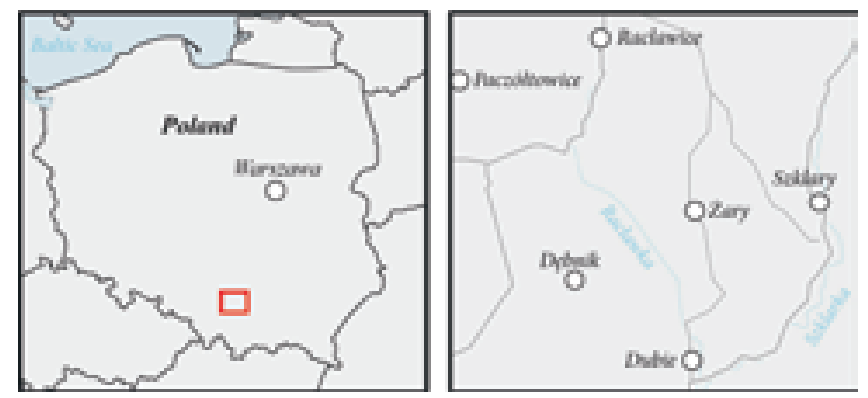

Abstract: The location and most interesting geological features of the Upper Devonian through Lower Carboniferous limestones in the Ractawka Valley were presented. The limestones outcropped almost continuously along the natural valley cutting. They comprise over 60 million years of continuous growth of the carbonate platform, which developed on the ancient terrane - the Upper Silesian Block. Geosites described herein may constitute a destination for geological trips for undergraduate students of Environmental Sciences, where they can actively discover the development of an ancient carbonate platform and accompanied post depositional structures.

Key words: Late Paleozoic, carbonate platform, Upper Silesian Block, geotourism

Abstrakt: $W$ dolinie Racławki znajduja się ważne geologicznie naturalne odstonięcia wapieni (od późnego dewonu do wczesnego karbonu). Wapienie te obejmuja okres ponad 60 milionów lat ciagłej sedymentacji węglanowej, która występowała na obszarze paleozoicznego kratonu - bloku górnoślaskiego. Opisane stanowiska moga być celem wycieczek geologicznych studentów pierwszego stopnia studiów przyrodniczych, w czasie których moga oni w aktywny sposób śledzić rozwój kopalnej platformy węglanowej i struktur postdepozycyjnych.

Stowa kluczowe: późny paleozoik, platforma węglanowa, blok górnoślaski, geoturystyka

\section{Introduction}

Every year, many tourists and students of Geoscience take tours to the northern vicinity of the Krzeszowice town, which offers beautiful landscapes developed along the southern edge of the Kraków-Częstochowa Upland. From the geological point of view, this area contains the southernmost part of the Silesian-Cracow Monocline (SCM) of the West European Platform (Fig. 1A), facing north to the tectonic depression
- the Krzeszowice Graben (Fig. 1C) (Żelaźniewicz et al., 2011). The older basement of the SCM contains the Devonian through Carboniferous folded sediments, included to the Variscides (Bukowy, 1961). These Paleozoic sediments consist of nearly $1200 \mathrm{~m}$ thick geological record of the Upper Paleozoic carbonate platform (Paszkowski, 1995), well outcropped, especially along the Racławka Valley, where the exposures are nearly continuous. This sedimentation took place in the epicontinental Moravo-Silesian Basin, along the shelves bordering the Upper Silesian Block, which was a part of a larger unit determined as the Brunovistulicum microcontinent (Fig. 1B) (e.g. Dudek, 1980; Kalvoda et al., 2003; Buła, Żaba, 2005, 2008). The tectonic history of the Brunovistulicum is dating back to the Precambrian. The Brunovistulicum consisted a piece of a continental plate derived from the Gondwana continent (Fig. 2) (e.g. Dadlez et al., 1994; Bełka et al., 2002; Nawrocki et al., 2004). In the late Paleozoic, the Brunovistulicum microcontinent was located near the southern margin of the Baltica ancient continent (e.g., Kalvoda et al., 2003), and finally amalgamated with the Bohemian Massif, during the Variscan orogeny (e.g., Van Breemen et al., 1982). During the Devonian through Carboniferous times (Fig. 2), the Brunovistulicum microcontinent occupied a nearly equatorial position (Kalvoda 2001, Kalvoda et al., 2003).

This paper presents geosites located in the southernmost part of the Kraków-Częstochowa Upland, where carbonate rocks were deposited in the shallow epicontinental sea, during the Late Paleozoic in warm climate conditions. These geosites might not only be interesting for tourists, but also for students of the Faculties of Geology and Geotourism better study the sedimentary geology of ancient environments.

\section{Geographical location of the exposures and geological setting}

The Racławka Valley (Fig. 1C ) is located in the southernmost part of the Kraków-Częstochowa Upland (KCU), $25 \mathrm{~km}$ west of the center of the Kraków, $5 \mathrm{~km}$ north of the Rudawa village, and between adjacent valleys - the Eliaszówka and Szklarka (Fig. 3). The Racławka creek (Fig. 1C) is the left tributary of the Rudawa River, flowing east along the Krzeszowice Trench. 

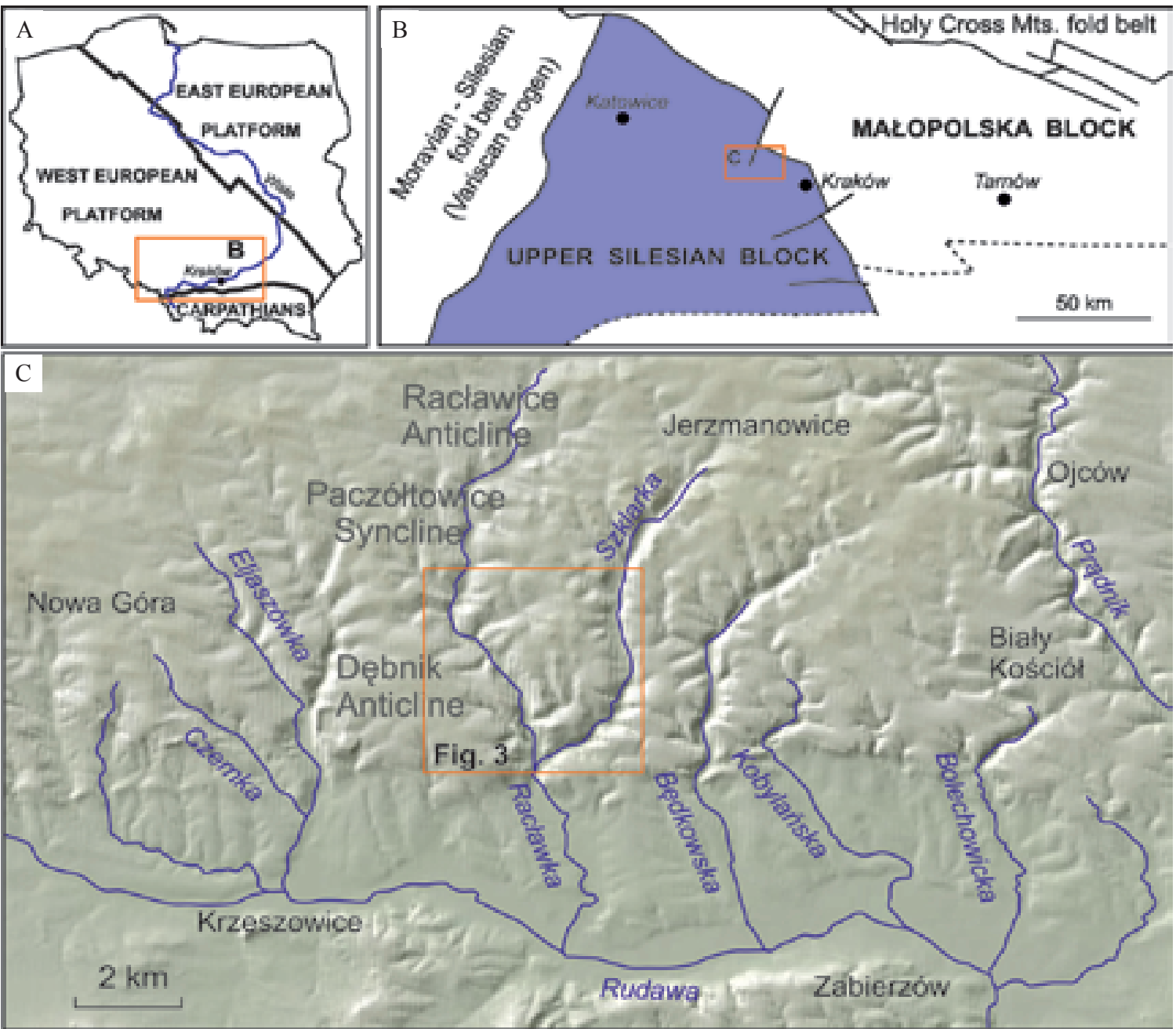

Fig. 1. Location of the study area: A - position on the background of main geologic units of Poland; B - position on the tectonic map of the southern part of Poland (without Permian-Mesozoic sediments; after Żelaźniewicz et al. 2011; simplified); C - geographic location of the Racławka Valley and its surroundings (within the Dębnik-Siewierz fold belt; after Bogacz 1980; background relief after http://mapy. geoportal.gov.pl/imap) - Lokalizacja obszaru badań: A - na tle głównych jednostek geologicznych Polski; B - tektoniczna mapa południowej Polski (bez osłony permo-mezozoicznej: za Żelaźniewicz et al., 2011; uproszczona); C - dolina Racławki wraz z otaczającymi miejscowościami (Bogacz, 1980; tło ilustracji za http://mapy.geoportal.gov.pl/imap)
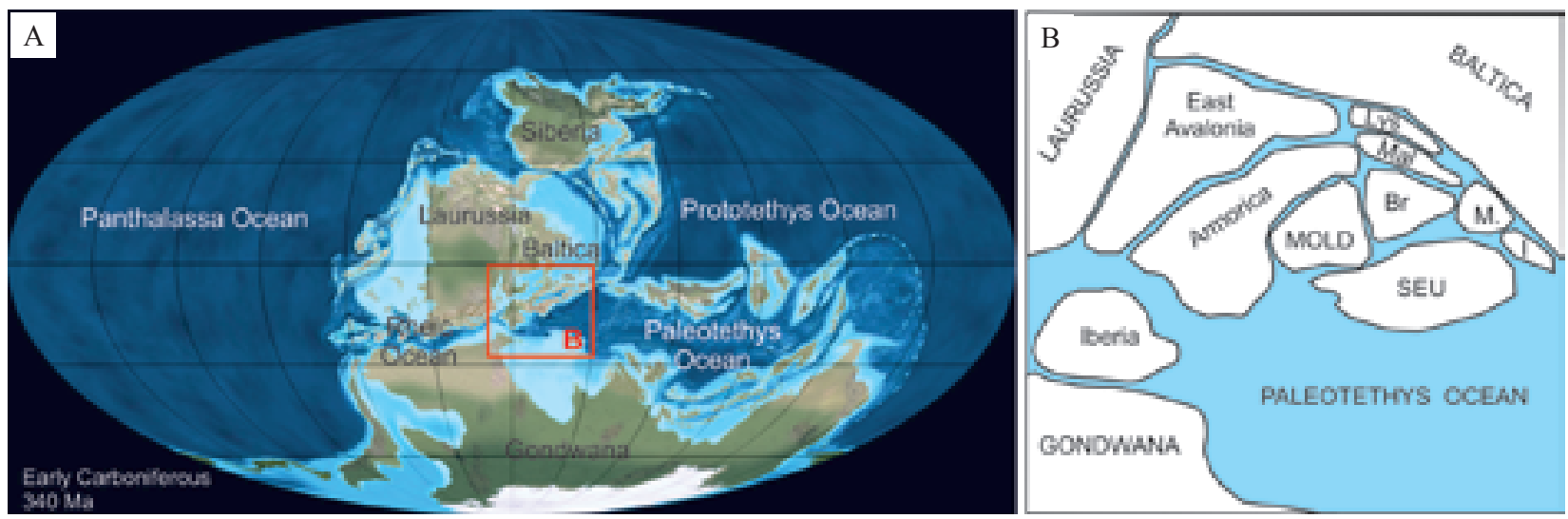

Fig. 2. Paleogeographic position of the studied region during the Early Carboniferous: A - global paleogeographic setting (adapted from Ron Blakey, http://jan.ucc.nau.edu/ rcb7/340moll.jpg); B - paleogeographic scheme showing the location of tectonic units and terranes discussed in the text (according to Kalvoda, 2002). Abbreviations: $\mathrm{Br}$ - Brunovistulian Terrane, I - Istanbul Zone, Lys - Łysogóry Terrane, M - Moesia Terrane, Mal - Małopolska Terrane, MOLD - Moldanubian Terrane, SEU - group of South European terranes • Pozycja paleogoegraficzna badanego obszaru we wczesnym karbonie: A - globalna mapa paleogeograficzna (Ron Blakey, http://jan.ucc. nau.edu/ rcb7/340moll.jpg); B - paleogeograficzny schemat ilustrujący lokalizację jednostek tektonicznych i teranów (Kalvoda, 2002). Rozwinięcie skrótów: $\mathrm{Br}$ - terran Brunovistulicum, I - zona Istanbul, Lys - terran Łysogór, M - terran mezyjski, Mal - terran małopolski, MOLD - terran moldanubski, SEU - grupa terranów południowoeuropejskich 
Geologically, two tectonically different complexes of rocks with discontinuity can be distinguished in the klippes hanging along the valley. The older complex is represented by tilted and folded Late Paleozoic limestones (Fig. 3). The younger complex lies almost horizontally. These deposits contain sandstones, gravestones and sandy limestones dating as Callovian and Oxfordian in age.

The Upper Paleozoic limestones were folded during the Variscan orogeny (Bukowy, 1961). Presently, they belong to the Dębnik-Siewierz fold belt (Żelaźniewicz et al., 2011), that creates the eastern part of the Upper Silesian Block (Buła et al., 2008; Fig. 1B). This fold belt occurs between Tarnowskie Góry, Siewierz and Krzeszowice towns and contains the
Carboniferous-Devonian folded sediments, built of synclines and anticlines, which are cut by numerous faults (Fig. 3).

The sediments outcropped along the Racławka Valley belong to the Upper Devonian (Fammenian) - Lower Carboniferous (Visean) succession that creates the Dębnik Anticline (e.g., Klimek, Koszarski, 1955; Gromczakiewicz-Lomnicka, 1974). They have been deposited as a carbonate platform in the Moravian-Silesian Basin (Bełka, 1987), of which the total thickness exceeds $1200 \mathrm{~m}$ (Paszkowski, 1995). These sediments have been deposited in various environments that included deep-water intra shelf basin, open shelf platform and ramp, and shallow water environments, with lagoons, as well as intertidal parts of the basin floor and sabkha (Łaptaś, 1982; Paszkowski, 1995).

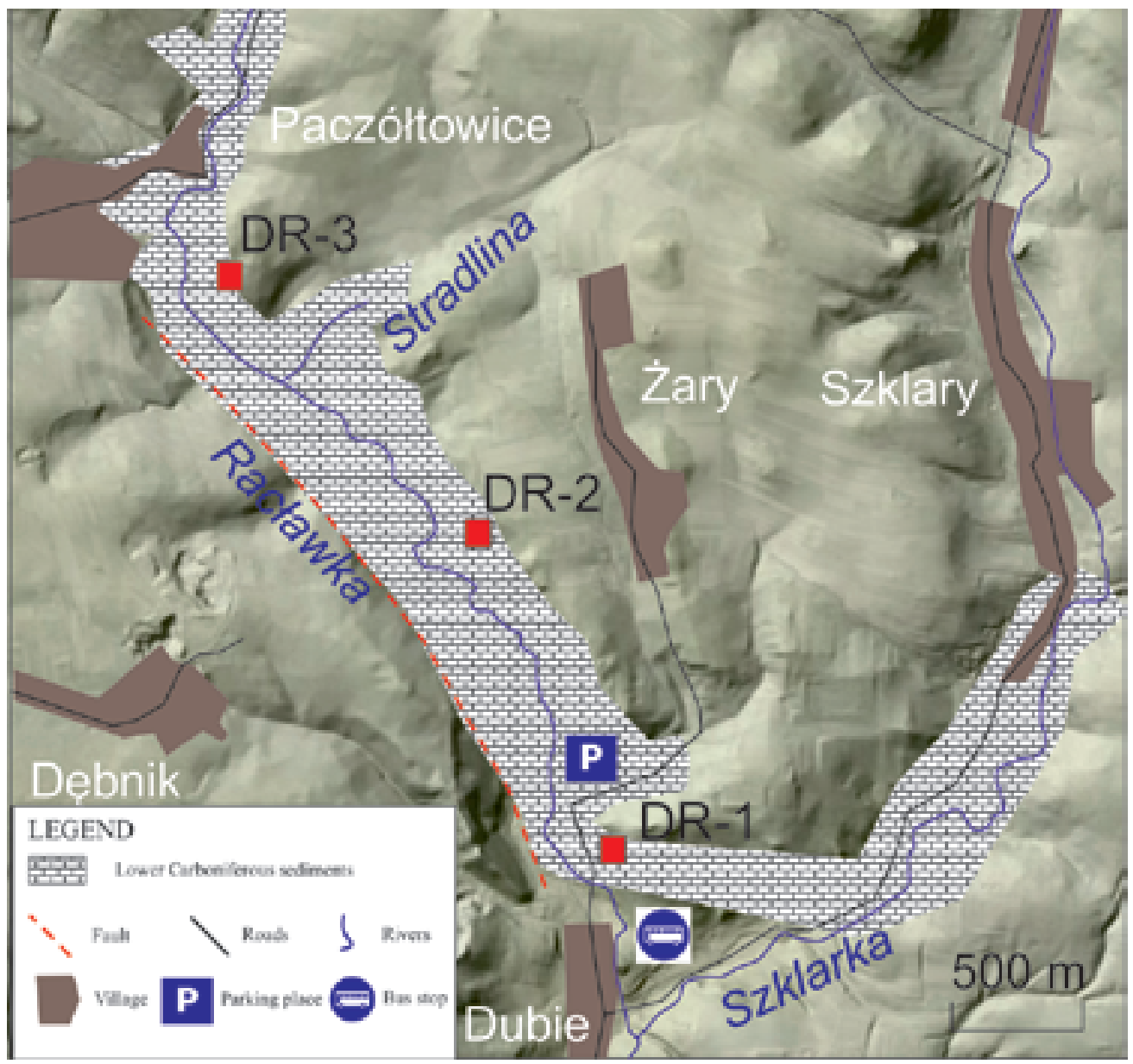

Fig. 3. Location of studied exposures along the Racławka Valley (red squares); position of the Lower Carboniferous sediments (after Bogacz, 1980; background relief after http://mapy.geoportal.gov.pl/imap/). Abbreviation of exposures names: DR-1 - Widoma; DR-2 Skała Opalona; DR-3 - Komarówka • Lokalizacja badanych odsłonięć wzdłuż doliny Racławki (czerwone punkty), wychodnie skał dolnego karbonu (Bogacz, 1980; tło ilustracji za http://mapy.geoportal.gov.pl/imap/). Nazwy i numeracja odsłonięć: DR-1 - Widoma; DR-2 - Skała Opalona; DR-3 - Komarówka

\section{Description of exposures}

Three well exposed outcrops of the Upper Paleozoic limestones are visible in the left bank of the Racławka creek, cutting into the east slopes of the valley (Fig. 3, 4). These are Widoma, Skała Opalona and Komarówka exposures. The exposures can be reached by walking from the Dubie bus stop and across the bridge over the Racławka creek. The first exposure - Widoma (Fig. 5) is located on the right side along the road leading to Żary village, $80 \mathrm{~m}$ behind the bridge (Fig. 3). To reach the second - Skała Opalona and third - Komarówka exposures, one should go north about $100 \mathrm{~m}$, than turn left onto the dust path along the Racławka Valley, which leads directly to the outcrops (Fig. 3, Fig. 6).

The field studies of exposures were supplemented by microscopic study of thin sections of the rock samples. 


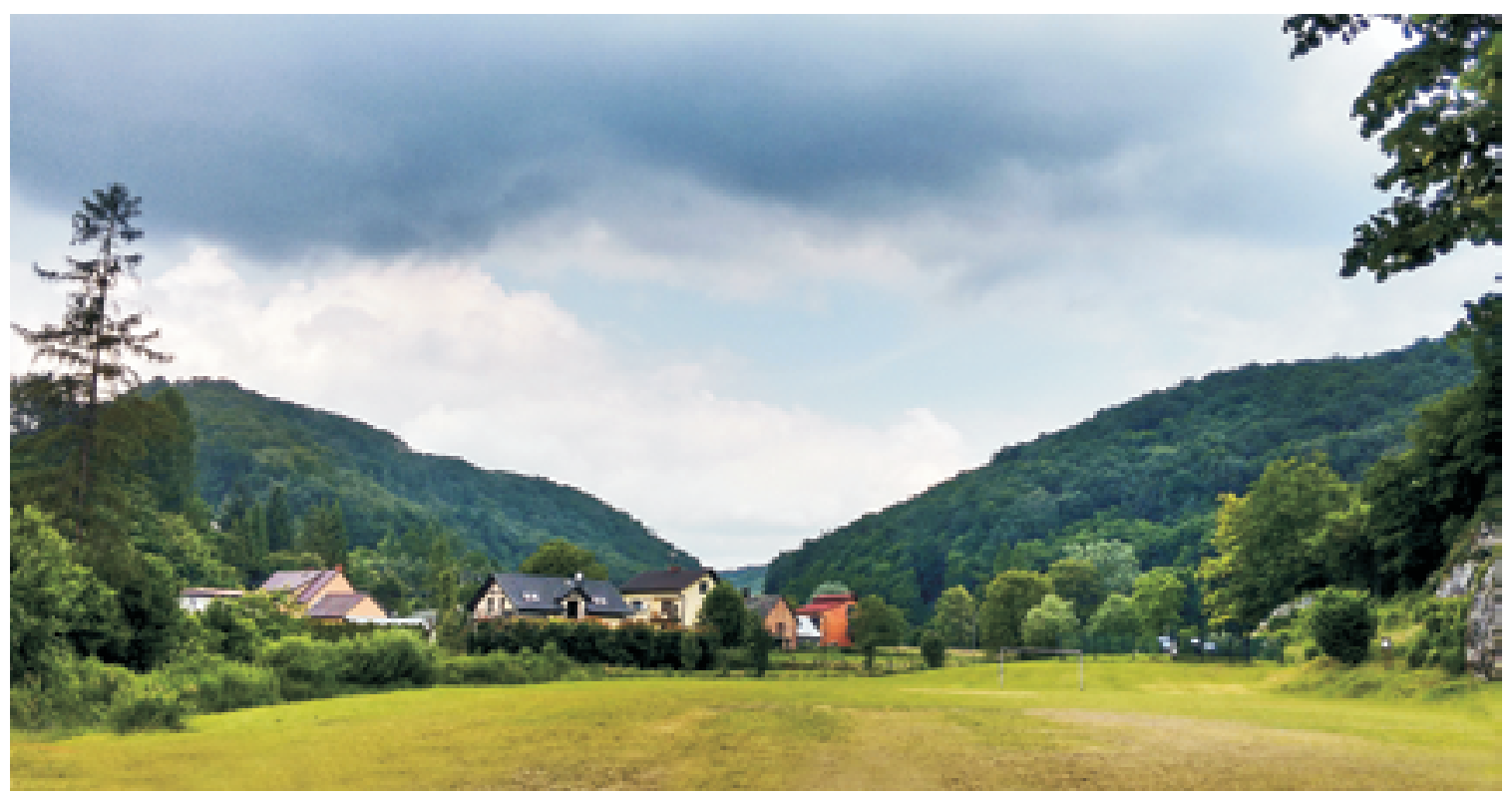

Fig. 4. General view on Racławka Valley from the center of Dubie Village, photo M. Bąk • Widok na dolinę Racławki z drogi DubieSzklary w centrum Dubia, fot. M. Bąk
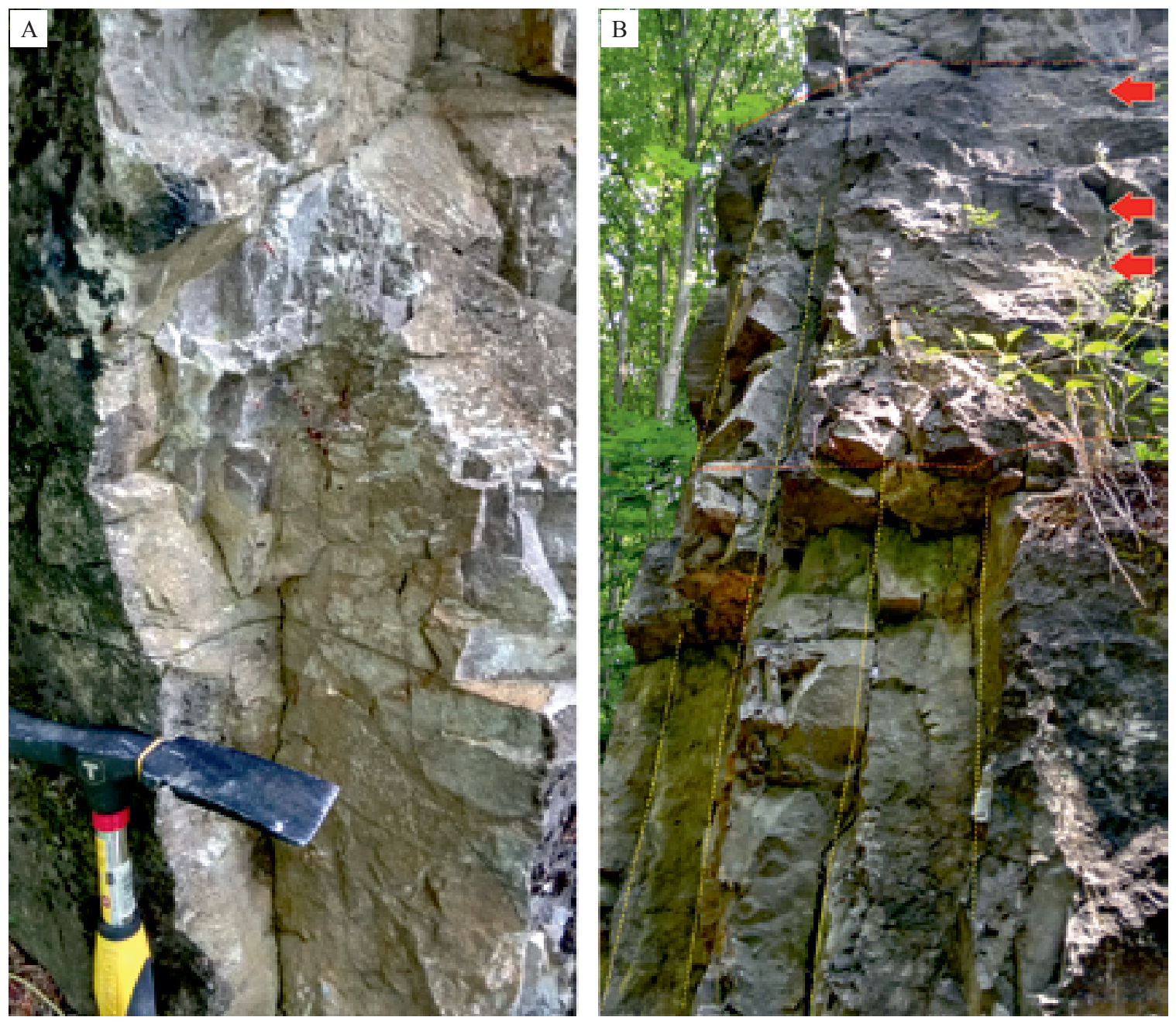

Fig. 5. Outcrop near the entry to the Racławka Valley: A - Skałka przy Mostku; the location of Late Fammenian limestones, photo S. Szczurek; B - zoom of the part of the Skałka przy Mostku exposure. Red line marks boundaries between successive beds; yellow lines marked tectonic joints; red arrows indicate lamination inside the beds, photo M. Bąk - Odsłonięcie Widoma w pobliżu doliny Racławki: A - odsłonięcie wapieni należących do późnego famenu, fot. S. Szczurek; B - fragment odsłonięcia w powiększeniu, z zaznaczonymi strukturami. Linie czerwone - granice warstw; linie żółte - cios; czerwone strzałki - laminacja, fot. M. Bąk 


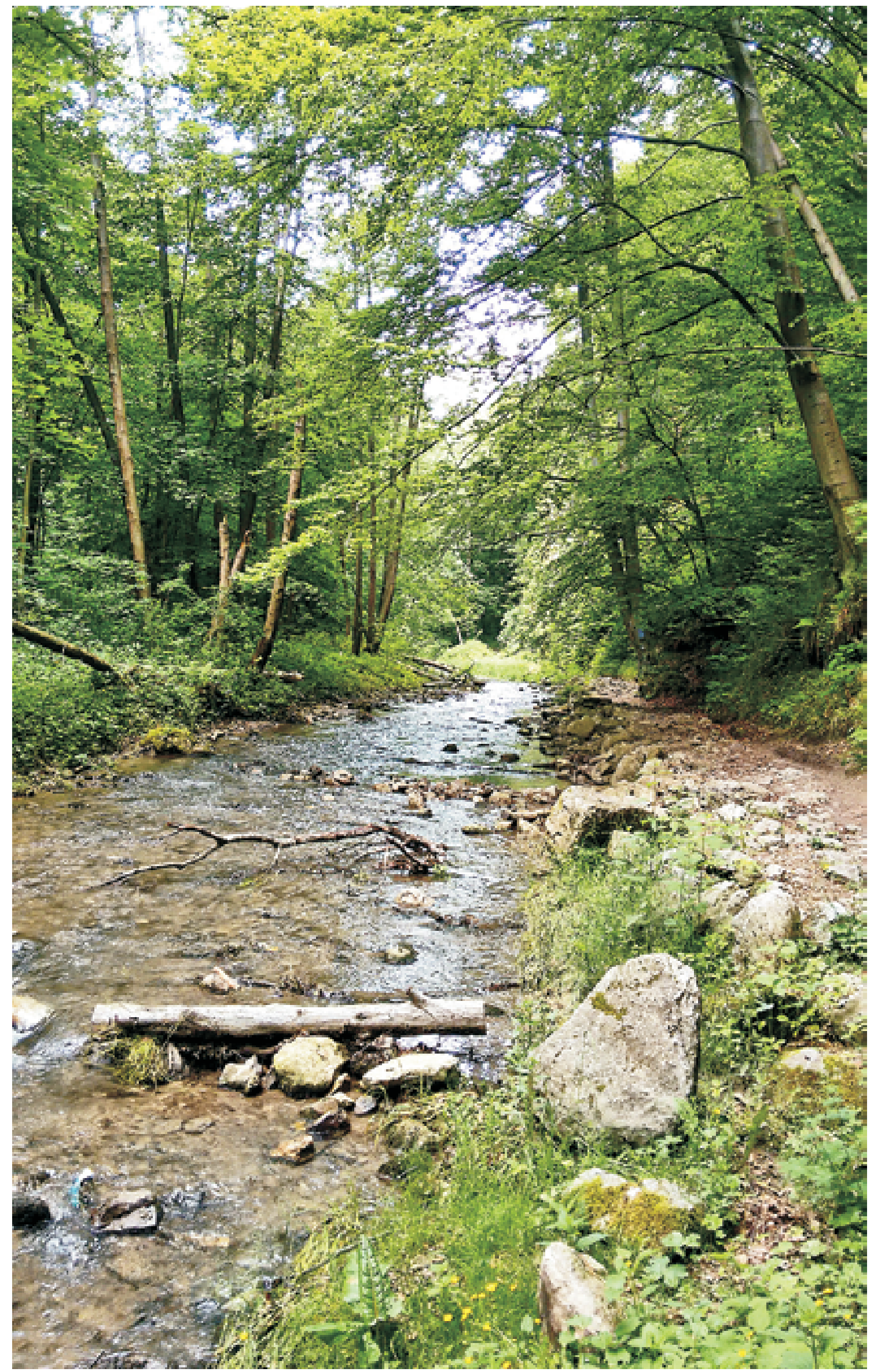

Fig. 6. The Racławka creek at the Skała Opalona. Touristic path at the right side, photo M. Bąk - Skała Opalona w dolinie Racławki. Ścieżka turystyczna po prawej, fot. M. Bąk 


\section{Widoma exposure}

The exposure consists of a klippe situated on the West slope of the Gora Widoma hill, overgrown with oak forests (N: 50'9'26.39'; E: 1941'27.63”). The $14 \mathrm{~m}$ long exposure is situated along the klippe wall (Fig. 5A). These are massive, light grey to pale pink limestones, moderately to thickly bedded, cut by vertical joints (Fig. 5B). Thin, perpendicular laminations are visible in many places on weathered bed surfaces (Fig. 5B). In some places, limestones are cut by cracks, filled by white and pink secondary calcite. In the microfacies view, the limestone contains abundant peloids and numerous bioclasts such as calcispheres, foraminifers, crushed trilobites, stromatoporoids, as well as single ostracods, crynoids and crushed spiriferids shells (Fig. 7). Limestones contain also rare, but visible by necked eye fossils, which are mostly brachiopods belonging to the spiriferids group. The microcomponents of the limestones have allowed us to classify them as peloidal wackstones, packstones and locally grainstones.
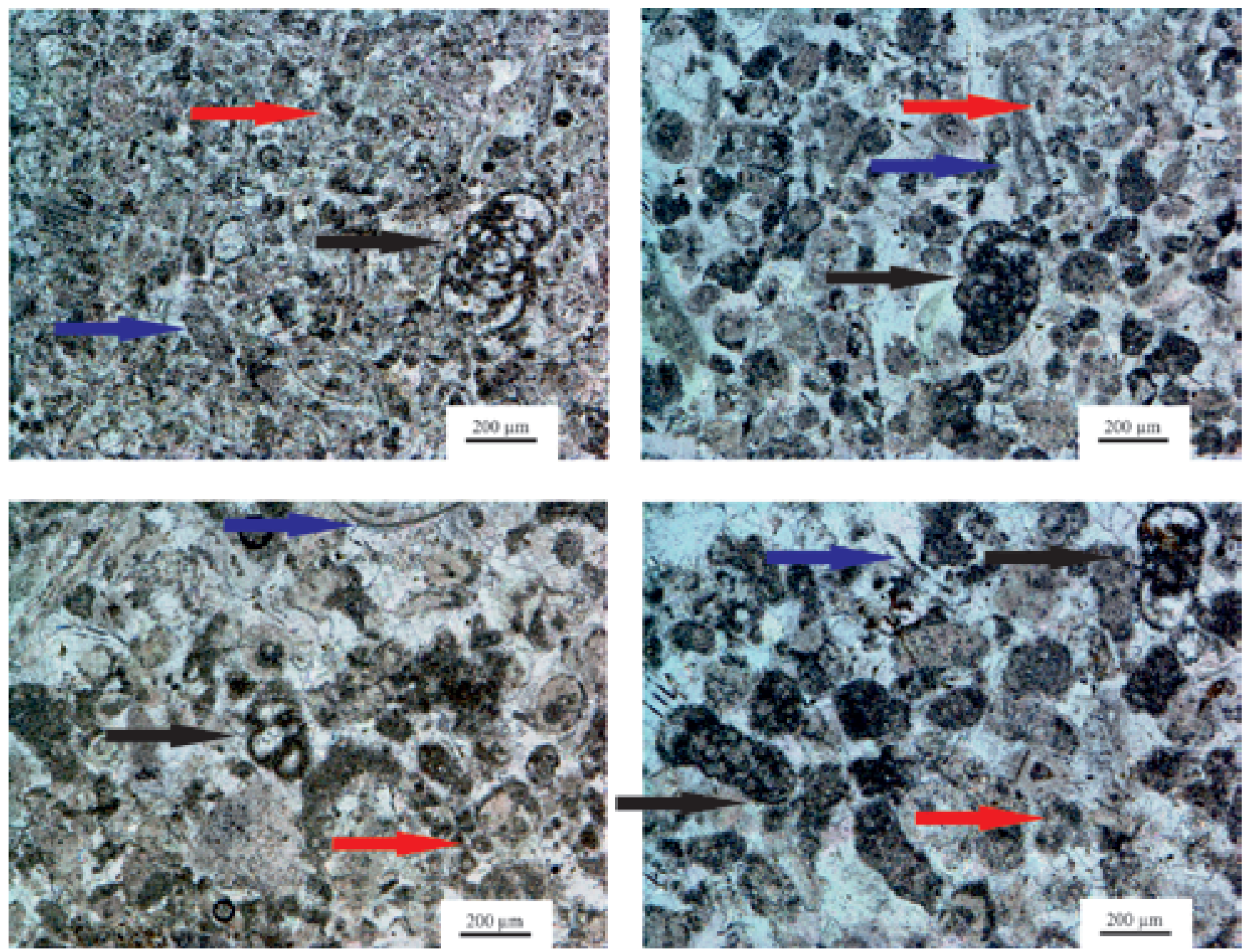

Fig. 7. Examples of typical microfacies from DR-1 profile, where peloidal packstones and grainstones with bioclasts (includes foraminifers, trilobites, gastropods etc.) dominate, photo S. Szczurek. Black arrows show specimens of foraminifers. Red arrows present peloids. Blue arrows point to the bioclasts (e.g. echinoderms). Blocky cement dominates in these thin sections. Syntaxial cement is common around parts of echinoderms - Przykład typowych mikrofacji z profilu DR-1, gdzie przeważają wapienie typu packstone/grainstone z peloidami i licznymi bioklastami (np. otwornice, trylobity, ślimaki), fot. S. Szczurek. Czarne strzałki wskazują otwornice, czerwone peloidy, a niebieskie pozostałe typy bioklastów (szkarłupnie). W płytce cienkiej dominuje cement blokowy, cement syntaksjalny towarzyszy szkarłupniom

\section{Skała Opalona exposure}

This exposure is accessible after walking $1300 \mathrm{~m}$ north along the Racławka Valley, from parking place situated at the road from Dubie to Żary villages (Fig. 3, Fig. 8). It is located on the left orographic side of the Racławka creek
(N: 50¹0’15.41"; E: 1940’57.32"). The limestones visible in the outcrop are thick to moderately bedded (Fig. 9), with singular beds up to $1 \mathrm{~m}$ thick (Fig. 9B).

In the cross-sections of the beds, the limestones are light grey to pale pink, with macroscopically visible fine lamination, left after fossilized stromatolites, which could be 
identified on some layers (Fig. 9A). Some beds contain also thin layers with intraclasts. The peloidal packstones and grainstones are the most common microfacies visible in thin sections made from rock samples taken from this exposure (Fig. 10). Bindstones, which contains carbonate clasts grains larger than $2 \mathrm{~mm}$ bound together by encrusting microbes, are present in some layers. They may alternate with sparfilled fenestral voids. Microfossils are rare in these deposits. Only some foraminifers, brachiopods and calcareous algae are present.

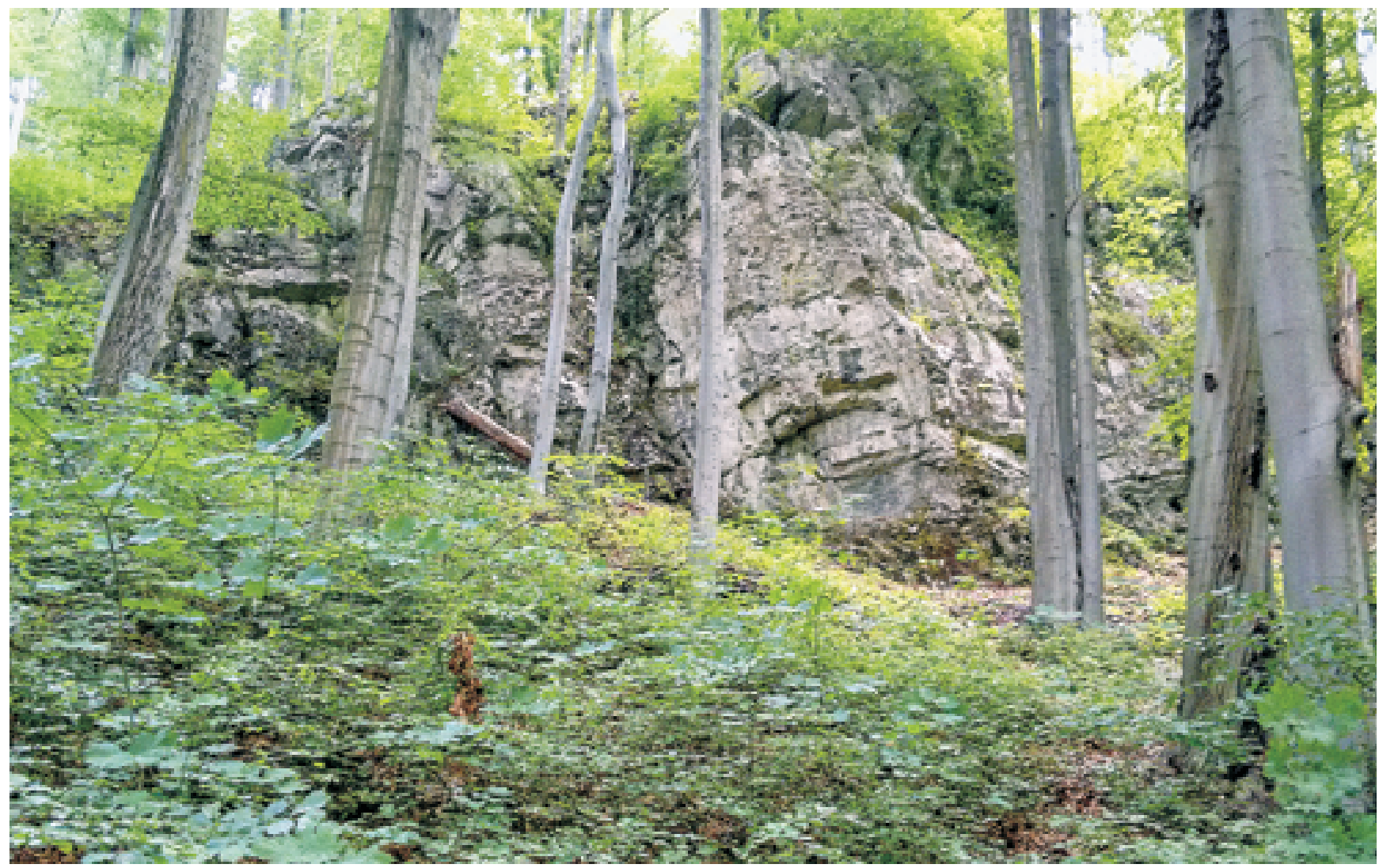

Fig. 8. Moderately to thick bedded limestone visible in one of the klippe at the Skała Opalona, photo M. Bąk • Srednio- i gruboławicowe wapienie widoczne w odsłonięciu Skała Opalona, fot. M. Bąk
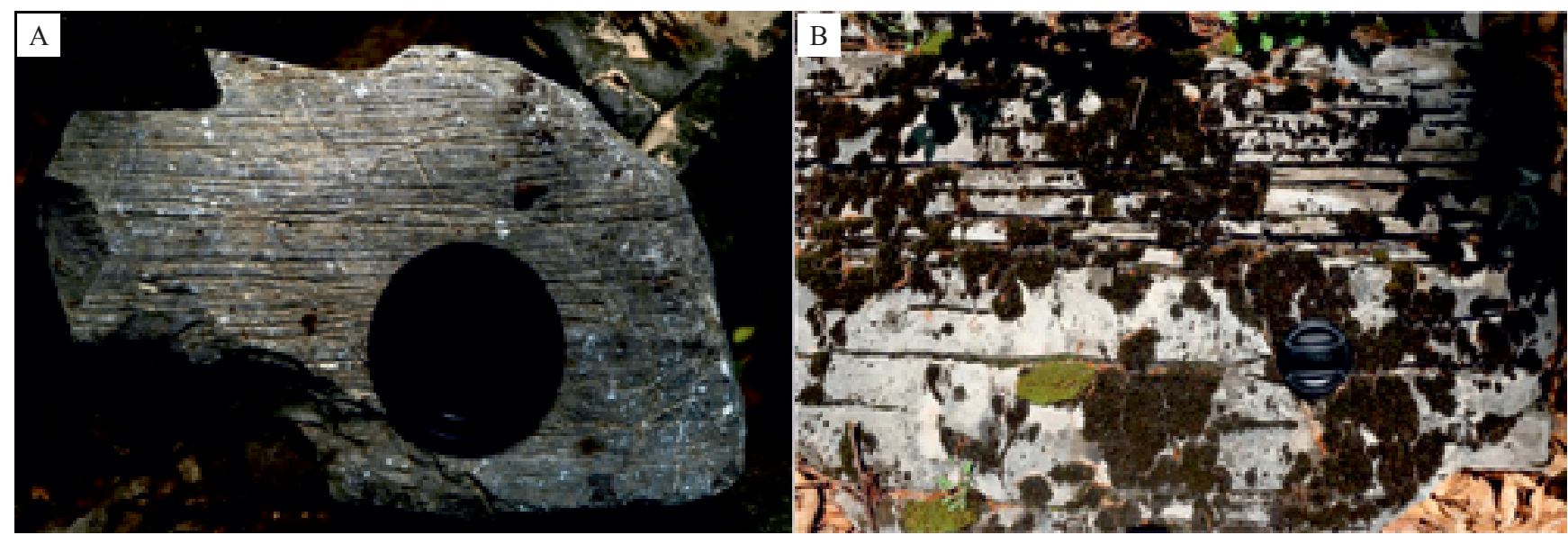

Fig. 9. Examples of limestones with two types of lamination in the Racławka Valley, highlighted by weathering. A - example of light grey to grey limestones, with clearly visible lamination, very thin layered (max. $2 \mathrm{~cm})$, near to Stradlina Gorge, photo S. Szczurek. B - example of layered limestones with Outcrop Skała Opalona. Well visible layers from 3-4 cm up to 20 or more centimeters, photo S. Szczurek - Przykłady wapieni o różnej laminacji w dolinie Racławki, podkreślone przez wietrzenie. A - wapienie jasnoszare do szarych z bardzo dobrze widoczną laminacją (grubość lamin max. $2 \mathrm{~cm}$ ) w pobliżu wąwozu Stradlina, fot. S. Szczurek. B - przykład warstwowanych wapieni z odsłonięcia nr 2 (Skała Opalona). Dobrze widoczne warstwy o miąższości od 3-4 cm do powyżej $20 \mathrm{~cm}$, fot. S. Szczurek 

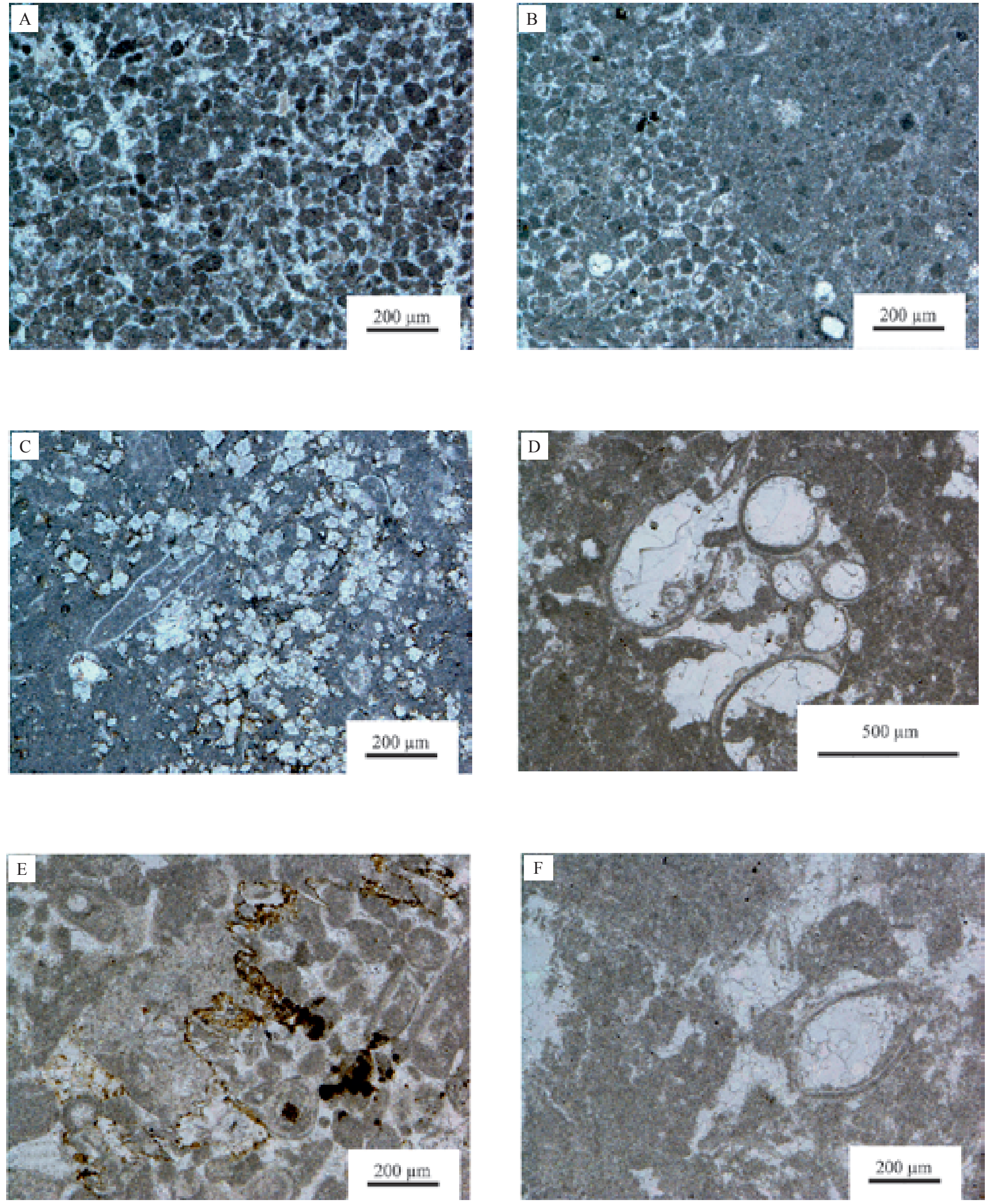

Fig. 10. Selected examples of diverse microfacies in DR-2 profile, photo S. Szczurek. A peloidal grainstone; B - transition from peloidal grainstones to peloidal packstones with bioclasts and calcispheres; $\mathrm{C}$ - bioclastic wackstones with pseudomorphosis of dolomite (possible dolomitisation during early diagenesis); D - bioclastic wackstones/packstones with serpulids; E - bioclastic grainstones with peloids cutted by stylolithes, here with no microfacies change; F - example of ostracods in bioclastic packstones/grainstones. • Wybrane przykłady zróżnicowanych mikrofacji z profilu DR-2, fot. S. Szczurek. A - wapienie grainstone z peloidami; B - przejście z wapieni typu grainstone z peloidami do wapieni typu packstone z peloidami, bioklastami i kalcisferami; $\mathrm{C}$ - wackstone bioklastyczny z pseudomorfozami dolomitu (możliwa dolomityzacja w trakcie wczesnej diagenezy); D - wackstone/packstone bioklastyczny z serpulami; E - grainstone bioklastyczny z peloidami i stylolitami, tutaj bez zmiany mikrofacji; F - packstone/grainstone z małżoraczkami 


\section{Komarówka exposure}

Going further north from the klippes belonging to the Skała Opalona exposure, we pass to the Stradlina Gorge (N: 50¹0’31.28”; E: 1940’25.21”) (Fig. 3, Fig. 11), which separates the Skała Opalona and Komarówka hills. Because of many small faults cutting the rocks herein, the next exposure named the Komarówka exposure consists of several, separate limestone complexes, 2-4 m meters thick, located along the touristic path, on the left side of the Racławka creek. The first klippe belonging to this exposure is outcropped $200 \mathrm{~m}$ north of Stradlina George (Fig. 12). The exposure consists of grey, massive limestone, without bedding. The limestones are strongly karstified. On the touristic track leading along the Racławka Valley, this klippe is named as
"Skałka z Nyżą". The next small klippes visible along the valley contain grey, strongly cemented limestones, moderately to thin bedded, with singular beds up to $20 \mathrm{~cm}$ thick (Fig. 13). In the microfacies view, these are fine-grained, peloidal, skeletal wacke- and packstone.

Bioclasts are common. They contain numerous calcispheres, moderately diverse foraminifers, ostracods, and crushed exoskeletons of small trilobites, which belong to the proetids. This is the only trilobite order documented in the Racławka Valley (Bąk et al., 2014). This trilobite group is the only one that survived the Late Devonian biodiversity crisis. The age of these deposits has been determined as the early Tournaisian, based on the presence of foraminiferal assemblages, which belong to earlandid and chernyshinellid groups (Bąk et al., 2014).

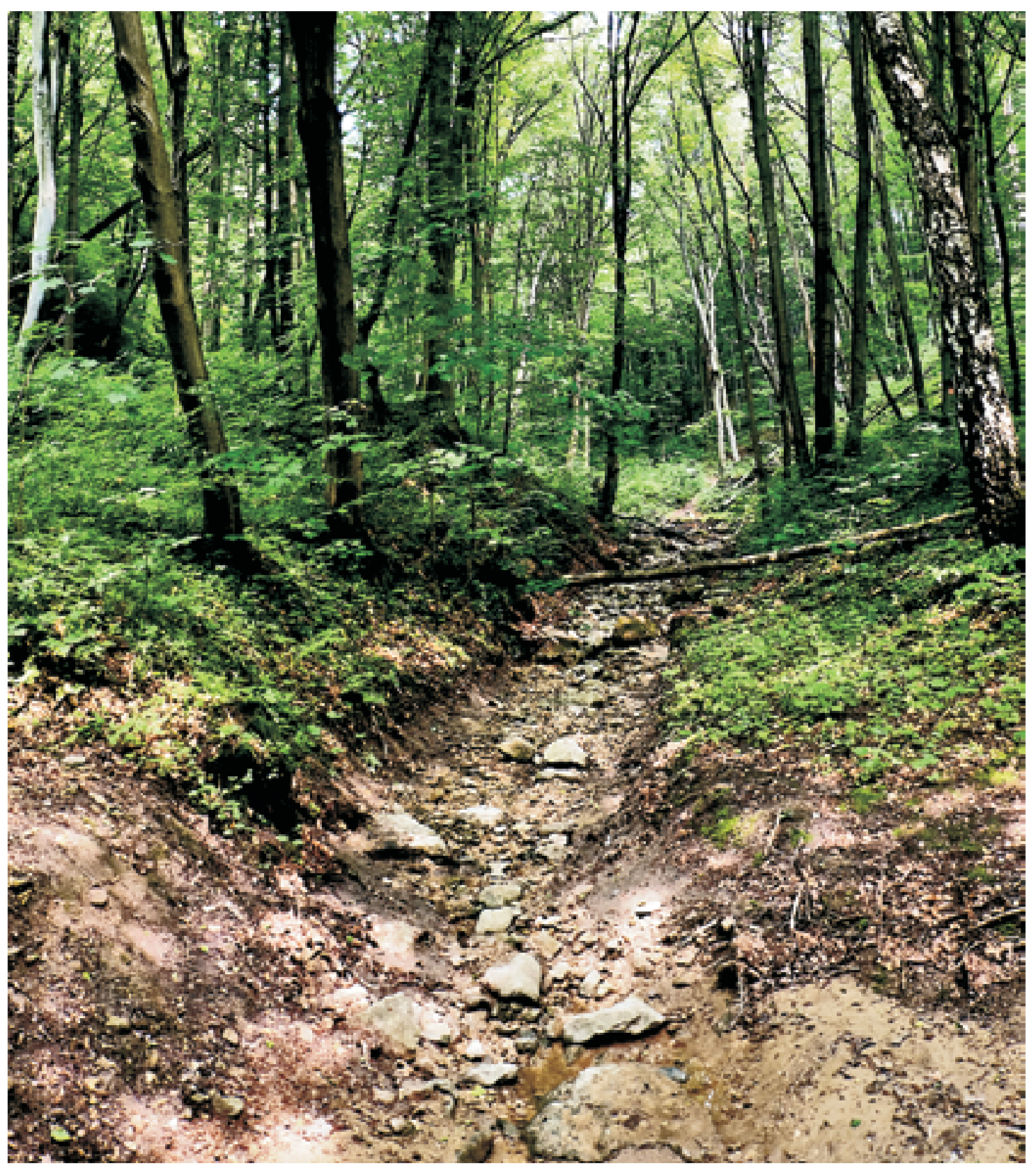

Fig. 11. The mouth of the Stradlina Gorge to the Racławka valley between Opalona and Komarówka hills, photo M. Bąk • Ujście wąwozu Stradlina do doliny Racławki pomiędzy wzgórzami Skała Opalona i Komarówka, fot. M. Bąk 


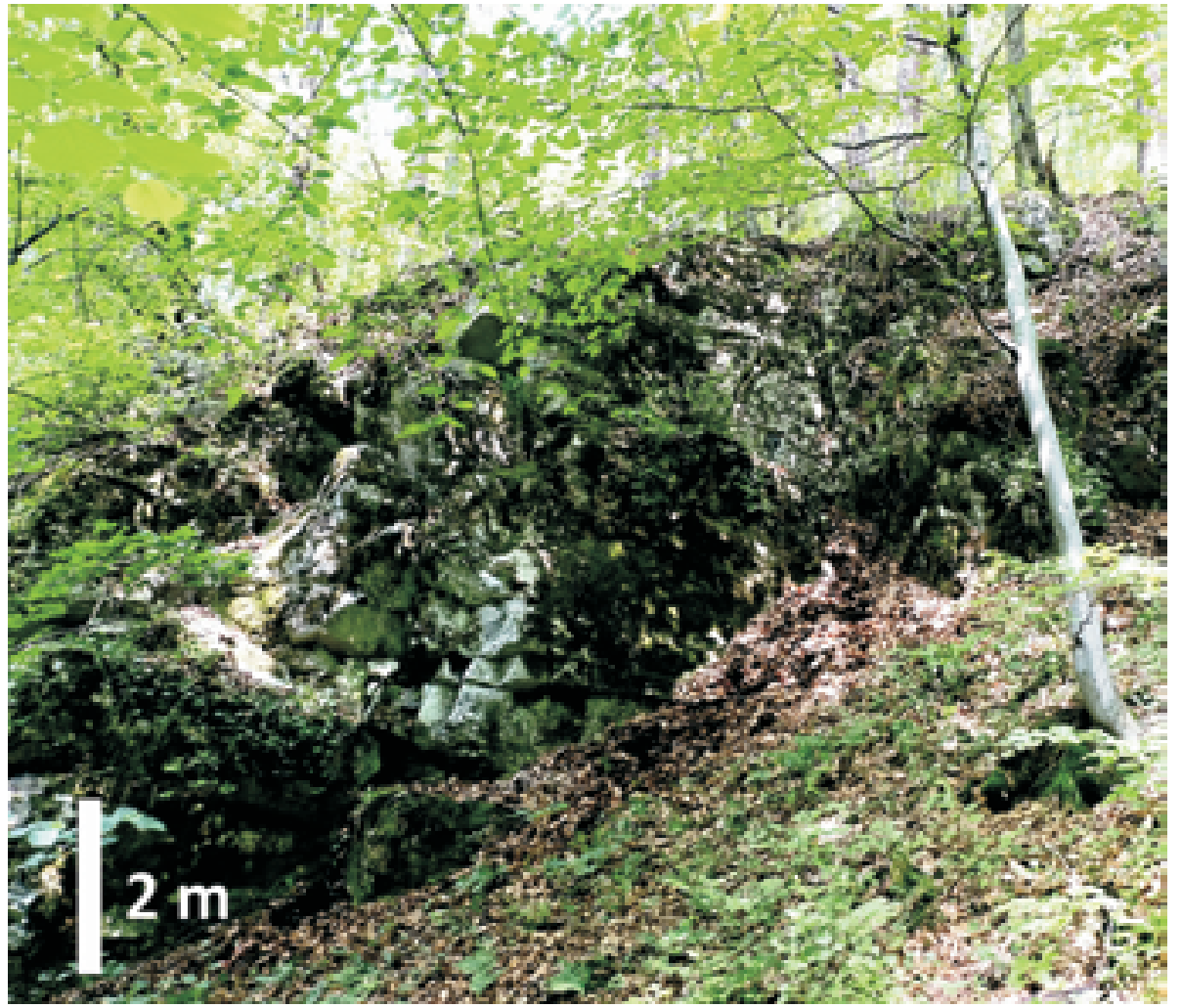

Fig. 12. The Komarówka Hill outcrop (about 9 meters heigh), where peloidal limestones bioclasts and accumulation of foraminifers (in thin sections) are present, characteristic of the Early Tournaisian age, photo S. Szczurek - Odsłonięcie nr 3 - Komarówka (około 9 m wysokości), gdzie obserwować można wapienie z peloidami i bioklastami (w płytkach cienkich). Obserwowane nagromadzenie otwornic wskazuje na wczesny turnej, fot. S. Szczurek
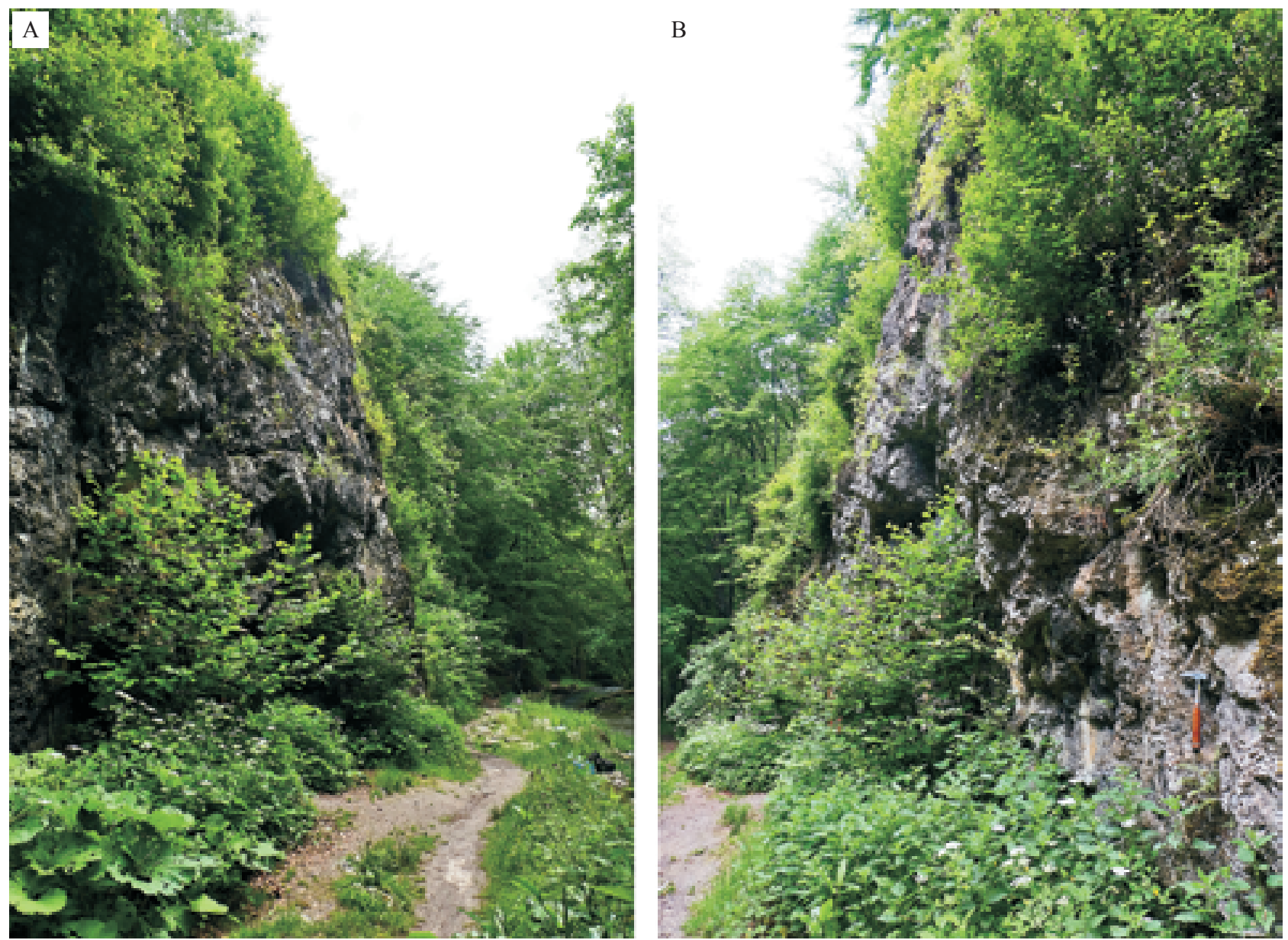

Fig. 13. First klippe from the series of exposures at the Komarówka Hill. A - Klippe (Skałka z Nyżą) visible along the touristic path; B - Close up of limestones build the klippe, photo M. Bąk, S. Szczurek • Pierwsza skałka z serii odsłonięć na wzgórzu Komarówka. A - Skałka z Nyżą i widoczny obok szlak turystyczny; B - wapienie budujące skałkę, fot. M. Bąk, S. Szczurek 


\section{Age and depositional environments}

The thick complex of grey limestones outcropped along the Racławka Valley are rich in microfossils, which can be used for age determination. The foraminiferal assemblages indicate the late Fammenian through late Visean age of these deposits, and can be correlated with the foraminiferal assemblages described from the Southern Ural (e.g., Kulagina, 2013), Belgium - Dinant and France - Avesnois (Conil, Lys, 1964), as well as the Czech Republic - Bohemian Massif, Moravia (Kalvoda, 2002).

Microfacies studies of the limestones indicate that their sedimentation took place in various environments, which include deep-water intra-shelf basins, open shelf platforms and ramps, and shallow water environments with lagoons, intertidal parts of the basin floor and sabkha (Łaptaś 1982; Paszkowski, 1995).

Limestones outcropped in the Widoma exposure were formed during the Late Fammenian through Early Tournaisian in the inner part of carbonate platform. The energy of depositional environment was relatively high, because fossil shells visible in thin sections were disintegrated and crushed. It is possible that some bioclasts may have been redeposited from shallower to deeper parts of the carbonate platform.

Limestones in the Skała Opalona and Komarówka exposures consist of younger sequence deposited during the late Devonian through early Carboniferous boundary, in an extremely shallow supra-tidal to sub-tidal environment, with episodes of occasional emersion (Tomaś, Zając, 1996). The presence of the crushed shells of brachiopods, fragments of lobes of trilobites, some ostracods and numerous other bioclasts indicate the high energy of the depositional environment, characterized by frequent tides. Similar deposits were described from shallow carbonate facies all over the world. The suggested an explanation for these phenomena as the presence of glaciation on the Gondwana continent during that time.

\section{Conclusion}

The exposures of the Upper Devonian through Lower Carboniferous limestones in the Racławka Valley are attractive and useful for the purpose of promoting and teaching of geological science. They make it possible to demonstrate and discuss many topics from various fields of geology e.g. sedimentology, paleontology and tectonics. The authors presented the studies on exposures which are based on microfacies (not visible by naked eye), but lead to a conclusion about the depositional environment on the carbonate platform developed in this region at the end of the Paleozoic. The stratigraphic and microfacies study of the limestone succession reveals the spatial and temporal change in their depositional settings. This carbonate platform was dominated by high-energy grainstones, rich in benthonic faunas, documenting the inner platform sequences. The observation proves that this particular location invokes a wide discussion on the correlation and global changes concerning the palaeoenvironment and tectonics.

\section{Acknowledgments}

This paper was supported by AGH grant no. 11.11.140.173 to M. Bak.

\section{References (Literatura)}

Bąk M., Dulemba P., Bąk K., 2014. Early Carboniferous trilobite remains from limestones in the Dębnik Anticline, southern Poland. Geology, Geophysics \& Environments, 39(1): 27-32.

Bełka Z., 1987. The development and decline of the Dinantian carbonate platform: an example from the Moravia - Silesia Basin. Poland. Geological Journal, special issue, 12: 177-188.

Bełka Z., Valvedre-Vaquero P., Dörr W., Ahrendt H., Wemmer K., Franke W., Schäfer J., 2002. Accretion of first Gondwana-derived terranes at the margin of Baltica. Geological Society, London, special series, 201: 19-36.

Bogacz K., 1980. Budowa geologiczna paleozoiku dębnickiego. Rocznik Polskiego Towarzystwo Geologicznego, 50(2): 183-208.

Bukowy S., 1961. Sprawa poszukiwań ropy naftowej w Hercynidach. Geological Quarterly, 5 (1): 57-61.

Buła Z., Żaba J., 2005. Pozycja tektoniczna Górnośląskiego Zagłębia Węglowego na tle prekambryjskiego i dolnopaleozoicznego podłoża. In: Jureczka J., Buła Z., Żaba J. (eds), Geologia i zagadnienia ochrony środowiska $w$ regionie górnoślaskim. Państwowy Instytut Geologiczny, Polskie Towarzystwo Geologiczne, Warszawa: 14-42.

Buła Z., Żaba J., 2008. Struktura prekambryjskiego podłoża wschodniej części bloku górnośląskiego (Brunovistulicum). Przegląd Geologiczny, 56: $473-480$.

Buła Z., Żaba J., Habryn R., 2008. Regionalizacja tektoniczna Polski - Polska południowa (blok górnośląski i blok małopolski). Przegląd Geologiczny, 56(10): 912-920.

Conil R., Lys M., 1964. Matériaux pour l'etude micropaléontologique du Dinantien de la Belgique et de la France (Avesnois). Mémoires de l'Institut Géologique de l'Université de Louvain, XXIII: 1-372.
Dadlez R., Kowalczewski Z., Znosko J., 1994. Some key problems of the pre-Permian tectonics of Poland. Geological Quarterly, 38: 169-190.

Dudek A., 1980. The crystalline basement block of the Outer Carpathians in Moravia: Bruno-Vistulicum. Academia, 90: 1-85.

Gromczakiewicz-Łomnicka A., 1974. Upper Visean conodont fauna from the Carboniferous limestone north of Krzeszowice (environs of Cracow, Poland). Rocznik Polskiego Towarzystwa Geologicznego, 44: 475-482.

Kalvoda J., 2001. Upper Devonian: Lower Carboniferous foraminiferal paleobiogeography and Perigondwana terranes at the Baltica-Gondwana interface. Geologica Carpathica, 52: 205-215.

Kalvoda J., 2002. Late Devonian-Early Carboniferous Foraminiferal Fauna: Zonations, Evolutionary Events, Paleobiogeography and Tectonic Implications. Folia Facultatis Scientiarum Naturalium Universitatis Masarykianae Brunensis, Geologia, 39: 1-213.

Kalvoda J., Devuyst F.X., Bábek O., Dvorák L., Rak S., Rez J., 2010. High-resolution biostratigraphy of the Tournaisian-Visean (Carboniferous) boundary interval, Mokrá quarry, Czech Republic. Geobios, 43(3): 317-331.

Kalvoda J., Leichmann J., Bábek O., Melichar R., 2003. Brunovistulian terrane (Central Europe) and Istanbul Zone (NW Turkey): Late Proterozoic and Paleozoic tectonostratigraphic development and paleogeography. Geologica Carpathica, 54: 139-152.

Klimek S., Koszarski L., 1955. Stratygrafia Dębnika w porównaniu z dewonem obszarów sąsiednich. Przegląd Geologiczny, 3(8): 388.

Kulagina E.I., 2013. Taxonomic diversity of foraminifers of the Devonian--Carboniferous boundary interval in the South Urals. Bulletin of Geosciences, 88(2): 265-282. 
Łaptaś A., 1982. Sedymentacja utworów węglanowych dewonu środkowego rejonu Dębnika. Studia Geologica Polonica, 75: 59-100.

Nawrocki J., Żylińska A., Buła Z., Grabowski J., Krzywiec P., Poprawa P., 2004. Early Cambrian location and affinities of the Brunovistulian terrane (Central Europe) in the light of palaeomagnetic data. Journal of the Geological Society, 161: 513-522.

Paszkowski M., 1995. Description of stops - Cracow region. In: Szulczewski M., Dvorak J. (eds.), Evolution of the Polish-Moravian Carbonate Platform in the Late Devonian and Early Carboniferous, Holy Cross Mountains, Cracow Upland, Moravian Karst. XIII International Congress on Carboniferous-Permian, Cracow 1995. Excursion. B-4: $23-28$

Tomaś A., Zając R., 1996. The Younger Paleozoic deposits in the basement of the Polish Western Carpathians. Geological Quarterly, 40(4): 521-542.

Van Breemen O., Aftalion M., Bowes D.R., Dudek A., Mísař Z., Povondra P., Vrána S., 1982. Geochronological studies of the Bohemian Massif, Czechoslovakia and their significance in the evolution of Central Europe. Transactions of the Royal Society of Edinburgh: Earth Sciences, 73(02): 89-108.

Żelaźniewicz A., Aleksandrowski P., Buła Z., Karnkowski P.H., Konon A., Oszczypko N., Ślączka A., Żaba J., Żytko K., 2011. Regionalizacja tektoniczna Polski. Komitet Nauk Geologicznych PAN, Wrocław, 1-60.

\section{Websites}

http://jan.ucc.nau.edu/ rcb7/340moll.jpg [accessed: 2016.05.15] http:// mapy.geoportal.gov.pl/imap [accessed: 2016.05.15] 